\title{
KONSEP UKHUWWAH ISLAMIYYAH SEBAGAI MATERI PAI
}

\author{
Ayoeb Amin 1) \\ ${ }^{1}$ Program Magister Pendidikan Islam, \\ Universitas Islam Sultan Agung (UNISSULA) Semarang
}

\begin{abstract}
Violent, brutal, and horizontal conflicts, as well as verbal abuse and slander on social media that sparked hatred in this country raise questions. Why did the Indonesian people who had been known friendly suddenly become violent? Is hospitality a forced attitude? Is the glue of unity called nationality not strong enough? Or are there other factors that trigger the emergence of violence and conflict? This paper will discuss about the concept of the Ukhuwwah Islamiyyah which is expected to become an Islamic Education material in schools and madrasah-madrasah throughout Indonesia. By understanding the meaning of Ukhuwwah, it is hoped that the Indonesian people will be more mature in living in a society, nation, and state. This article using a religious approach, because the majority of the population of Indonesia is Muslim. It is hoped that through this approach it can achieve the desired goals, not even be disastrous.
\end{abstract}

Keywords: Ukhuwwah Islamiyyah, PAI Material, Religiosity

\begin{abstract}
Abstrak
Tindakan kekerasan, brutal, dan konflik horizontal, serta caci maki dan fitnah di media sosial yang menyulut kebencian di negeri ini memunculkan berbagai pertanyaan. Mengapa masyarakat Indonesia yang selama ini dikenal ramah tiba-tiba menjadi beringas? Apakah keramahan itu suatu sikap yang dipaksakan? Apakah perekat kesatuan yang disebut kebangsaan belum kokoh kuat? Atau ada faktor lain yang memicu munculnya kekerasan dan konflik? Tulisan ini akan membahas tentang Konsep Ukhuwwah Islamiyyah yang diharapkan menjadi materi Pendidikan Agama Islam di sekolah-sekolah dan madrasah-madrasah di seluruh Indonesia. Dengan memahami makna Ukhuwwah diharapkan masyarakat Indonesia akan lebih dewasa dalam hidup bermasyarakat, berbangsa, dan bernegara. Penulisan artikel ini dengan menggunakan pendekatan religius, karena mayoritas penduduk Indonesia beragama Islam. Diharapkan melalui pendekatan tersebut bisa mencapai sasaran yang diinginkan, bukan malah menjadi petaka.
\end{abstract}

Kata Kunci: Ukhuwwah Islamiyyah, Materi PAI, religiusitas

\section{PENDAHULUAN}

Masyarakat Indonesia adalah merupakan masyarakat majemuk. Majemuk dalam kesukuannya, majemuk dalam bahasanya, majemuk dalam budayanya, dalam tingkat pendidikannya, agamanya, faham, dan kepercayaannya, dalam tingkat sosial dan ekonominya, dan dalam hal-hal lainnya. Kemajemukan itu tidak mungkin dinafikan. Justeru kemajemukan dinilai sebagai salah satu khazanah budaya bangsa. 
Bhineka Tunggal Ika adalah motto yang menggambarkan keinginan bersama untuk melestarikan dan menyatukan kemajemukan tanpa harus mengorbankan salah satu unsur yang ada dalam kemajemukan.

Indonesia dinilai oleh masyarakat internasional telah berhasil menyatukan kemajemukan dalam suatu negara yang disebut Negara Kesatuan Republik Indonesia (NKRI). Keberhasilan Indonesia itu dinilai sebagai suatu prestasi yang patut diacungi jempol, karena sangat sedikit sekali negara yang berhasil menyatukan berbagai unsur kemajemukan dalam wadah negara kesatuan. Persatuan dan kesatuan yang menjadikan keadaan aman dan damai yang didambakan setiap anggota masyarakat Indonesia ternyata rentan dalam menghadapi gesekan-gesekan dan goncangangoncangan yang menyertai dinamika sosial politik yang sedang terjadi di dalam masyarakat. Gesekan dan goncangan itu diperburuk oleh kehadiran teknologi komunikasi dan informasi. Dengan teknologi itu orang dengan mudah melakukan ujaran kebencian, penistaan agama, fitnah, menyebar berita bohong, dan lain sebagainya.

Beberapa tahun yang lalu konflik horizontal di Ambon, Sambas, Sampit dan Palangkaraya, dan di penghujung tahun 2016 terjadi penistaan agama, serta terakhir di tahun 2018 ini terjadi tindak kekerasan terhadap ulama'. Kesemuanya itu adalah bukti konkret bahwa di dalam kemajemukan yang diikat oleh unsur kebangsaan belum bisa disebut solid. Konflik horizontal di Ambon dipicu oleh sentimen keagamaan. Sedangkan di Sambas, Sampit, dan Palangkaraya dipicu oleh sentimen kesukuan (ras, etnis). Justru yang sangat memprihatinkan adalah konflik horizontal antar sesama muslim seperti yang terjadi di Pekalongan, Banyuwangi, Madura dan daerah-daerah lain pada dekade sebelumnya.

Tindakan kekerasan, brutal, dan konflik horizontal, serta caci maki dan fitnah di media sosial yang menyulut kebencian di negeri ini memunculkan berbagai pertanyaan. Mengapa masyarakat Indonesia yang selama ini dikenal ramah tiba-tiba menjadi beringas? Apakah keramahan itu suatu sikap yang dipaksakan? Apakah perekat kesatuan yang disebut kebangsaan belum kokoh kuat? Atau ada faktor lain yang memicu munculnya kekerasan dan konflik?

Tulisan ini akan berbicara tentang Konsep Ukhuwwah Islamiyyah yang diharapkan menjadi materi Pendidikan Agama Islam di sekolah-sekolah dan madrasah-madrasah di seluruh Indonesia. Dengan memahami makna Ukhuwwah 
diharapkan masyarakat Indonesia akan lebih dewasa dalam hidup bermasyarakat, berbangsa, dan bernegara. Penulisan artikel ini dengan menggunakan pendekatan religius, karena mayoritas penduduk Indonesia beragama Islam. Diharapkan melalui pendekatan tersebut bisa mencapai sasaran yang diinginkan, bukan malah menjadi petaka.

\section{PEMBAHASAN}

\section{Pengertian Ukhuwwah Islamiyyah}

Ukhuwwah ditulis sesuai dengan aslinya menggunakan tasydid pada huruf wawu, merupakan bentuk infinitif dari kata kerja $\hat{a} k h a$, yang berarti persaudaraan. Islamiyyah berasal dari kata Islam, yaitu agama yang diturunkan Allah melalui RasulNya Muhammad Saw berisi perintah, larangan, dan petunjuk untuk kemaslahatan dan kebaikan umat manusia di dunia dan di akhirat. Ukhuwwah Islamiyyah terdiri dari dua kata yang di dalam bahasa Arab disebut tarkib na'ti. Artinya, susunan yang terdiri dari kata yang disifati dan kata sifat (ajektif). Kata yang disifati adalah Ukhuwwah, sedang kata sifatnya adalah Islamiyyah. Kata Islam sendiri sebenarnya tidak bisa menjadi sifat karena sebagai kata benda. Setiap kata benda yang akan dijadikan kata sifat harus memperoleh tambahan " $y a^{\prime}$ nisbah". Dengan demikian diketahui bahwa Ukhuwwah Islamiyyah berarti persaudaraan yang Islami. Artinya, persaudaraan yang bersifat Islami, atau persaudaraan yang berdasarkan dan dijiwai oleh nilai-nilai ajaran Islam, bukan persaudaraan sesama orang Islam (muslim) sebagaimana yang difahami oleh sebagian masyarakat.

Ukhuwwah Islamiyyah dengan pengertian di atas didukung oleh alasan-alasan antara lain:

1. Alquran dan Assunnah memperkenalkan bermacam-macam persaudaraan, tidak hanya terbatas persaudaraan antar sesama muslim.

2. Dalam bahasa Arab, kata sifat selalu harus disesuaikan dengan kata yang disifati. Apabila kata yang disifati berbentuk indefinitif dan feminin, maka kata sifatnya harus pula demikian, seperti Ukhuwwah Islamiyyah. Kata yang disifati, yaitu Ukhuwwah dalam bentuk indefinitif dan feminin. Karena itu sifatnya, yaitu Islamiyyah harus indefinitif dan feminin pula. Berbeda kalau kata yang disifati ditambah "al" (pertanda definitif) sehingga menjadi al-Ukhuwwah, maka kata sifatnya harus juga ditambah "al" sehingga menjadi al-Islamiyyah. Sifat harus 
senantiasa mengikuti yang disifati (mausuf), baik dalam ta'nits dan tadzkir, maupun dalam ta'rif dan tankir, serta ta'rib-nya.

\section{Landasan Ukhuwwah}

Landasan Ukhuwwah secara filosofis dan operasional adalah Islam. Sumber ajaran Islam adalah Alquran dan Assunnah. Kedua sumber itu sekaligus menjadi acuan utama Ukhuwwah. Di dalam dua sumber itu, Ukhuwwah (persaudaraan) tidak hanya berlaku untuk kalangan sesama muslim. Ukhuwwah yang diajarkan Islam adalah Ukhuwwah dengan siapa saja, baik sesama muslim atau sesama manusia tanpa dibatasi oleh nasab/keturunan, agama, ras, etnis, suku, golongan, asal daerah, dan status sosial, ekonomi, dan politiknya. Bahkan Islam mengajarkan Ukhuwwah dengan tetumbuhan, binatang, dan makhluk Allah lainnya.

Landasan ini menjadikan seseorang yang telah menandatangani kontrak perjanjiannya dengan Allah melalui pengikraran kalimat syahadat, merefleksikan seluruh isi perjanjiannya dengan Allah, yaitu mengamalkan hukum dan aturan-aturan yang ada di dalam Alquran dan Assunnah dalam perbuatan, ucapan, dan sikap keseharian, termasuk dalam hidup bersaudara dengan sesama manusia dan sesama makhluk Allah lainnya.

\section{Macam-macam Ukhuwwah Dalam Alquran}

Alquran menyebut kata $a k h$ (saudara) dalam bentuk tunggal sebanyak 52 kali. Penyebutan kata tersebut menunjukkan keragaman makna sesuai dengan konteksnya. Atas dasar itu diketahui bahwa macam-macam Ukhuwwah di dalam Alquran adalah:

- Saudara kandung atau saudara seketurunan/nasab (QS al-Nisa': 23) dan saudara sepersusuan

- Saudara yang dijalin oleh ikatan keluarga (QS Thaha: 29-30)

- Saudara dalam arti sebangsa, walaupun tidak seagama (QS al-A'raf: 65)

- Saudara semasyarakat, walaupun berselisih faham (QS Shad: 23)

- Saudara seagama (QS al-Hujurat: 10).

Bentuk jamak kata akh ada banyak, antara lain ikhwān dan ikhwah. Ikhwān digunakan untuk makna persaudaraan yang tidak diikat oleh hubungan nasab/keturunan. Sedangkan ikhwah digunakan untuk makna persaudaraan yang diikat oleh hubungan nasab/keturunan, kecuali hanya satu kali Alquran 
menggunakannya untuk persaudaraan yang berdasarkan keimanan (akidah Islamiah) (QS al-Hujurat: 10).

Pembagian Ukhuwwah yang bermacam-macam itu mengandung konsekuensi hukum. Ukhuwwah senasab (sekandung atau seayah atau seibu) tidak boleh menikah, dan mereka saling mewarisi. Ukhuwwah sepersusuan tidak boleh menikah, dan mereka tidak saling mewarisi. Ukhuwwah seagama (Islam) dibolehkan menikah, dan mereka tidak saling mewarisi. Ukhuwwah seagama menekankan aspek sosiologis, Ukhuwwah sesama manusia menekankan aspek kemanusiaan, dan Ukhuwwah sekemakhlukan menekankan aspek ketundukannya kepada Sang Khalik, yaitu Allah Swt.

\section{Ukhuwwah Dalam Ajaran Islam}

1. Dasar Pembentukan Masyarakat

Islam menyebut untuk masyarakat yang para anggotanya menganut satu keyakinan dengan sebutan ummah (QS al-Anbiya': 92). Kata ummah berasal dari akar kata amm, yang memiliki makna: maksud dan jalan (Ibn Manzur, 1968: XII/22). Dengan demikian, ummah ialah suatu masyarakat di mana sejumlah orang yang mempunyai keyakinan dan tujuan yang sama, menghimpun diri secara harmonis dengan maksud untuk bergerak maju ke arah tujuan bersama (Ali Syariati, 1982: 159).

Dasar pembentukan masyarakat adalah keyakinan tauhid (akidah tauhid). Akidah tauhid ini menempatkan seluruh anggota masyarakat pada posisi dan kedudukan yang sama. Pembentukan masyarakat yang berdasarkan akidah tauhid akan memberikan kelebihan-kelebihan, antara lain:

a. Akidah tauhid sebagai tali pengikat yang kokoh kuat dan efektif untuk mempersatukan seluruh anggota masyarakat tanpa batas ras keturunan dan wilayah teritorial. Di bawah panji-panji akidah tauhid mereka seluruhnya menjadi saudara (QS al-Hujurat: 10).

b. Akidah tauhid menghilangkan fanatisme. Fanatisme ialah suatu faham yang mengharuskan pembelaan terhadap individu atau lembaga dalam segala posisi, baik salah atau benar. Fanatisme dikecam keras oleh Islam. Rasulullah Saw menyebutnya sebagai bau busuk, bahkan beliau tidak memasukkan orang yang fanatis ke dalam golongannya (al-Hadits). 
c. Akidah tauhid menempatkan ukuran keutamaan seseorang pada ketakwaan (QS al-Hujurat: 13), bukan pada status sosial atau status ekonomi (Zaidan, 1976: 98-99).

Kendati Islam telah menetapkan ketentuan di atas, tidak berarti masyarakat Islam menolak keberadaan non muslim. Islam menempatkan non muslim sebagai dzimmi. Mereka dilindungi dan diperlakukan seimbang dengan kewajiban yang dilaksanakannya terhadap masyarakat Islam.

2. Prinsip-prinsip Kehidupan Bermasyarakat

Dengan menggunakan kata ummah sebenarnya Islam telah menggariskan pertanggungjawaban intelektual serta gerakan bersama sebagai landasan filosofis sosialnya. Kendati demikian, Islam masih melengkapi dengan prinsip-prinsip umum sebagai landasan operasional untuk pengembangan eksistensi ummah. Prinsip-prinsip tersebut adalah:

a. Prinsip Musyawarah (tasyâwur, conseil) (QS al-Syurâ: 38; Ali Imran: 159)

Prinsip ini memperlancar arus komunikasi timbal balik. Penyumbatan arus ini menyebabkan munculnya ketegangan-ketegangan sosial. Melalui musyawarah, sesulit apapun persoalan bisa diselesaikan.

b. Prinsip Persamaan (musâwât, egalité) (QS al-Hujurât: 13)

Setiap orang memiliki tingkat derajat yang sama, tidak ada keunggulan antara individu yang satu atas yang lain, tidak ada pengkultusan dan tidak ada pula orang yang kebal hukum. Rasulullah konsisten menegakkan prinsip ini sebagaimana diungkapkan dalam sumpahnya: "Demi Allah, kalau Fatimah binti Muhammad mencuri, pasti Muhammad akan memotong tangannya".

c. Prinsip Keadilan ('adâlah, justice) (QS al-Mâidah: 8)

Keadilan sosial menjadi unsur penentu dalam mewujudkan ketenteraman dan ketenangan masyarakat. Ketimpangan, ketegangan, dan kecemburan sosial banyak disebabkan tidak adanya keadilan sosial. Keadilan sosial ini terkait erat dengan keadilan ekonomi, politik, dan hukum.

d. Prinsip Kerjasama (ta'âwun, coopération) (Q.S. al-Mâidah: 2).

Sebagai makhluk sosial, manusia tidak mungkin mampu memenuhi basic neednya sendiri. Manusia tidak bisa menolak untuk bekerjasama dengan sesamanya dalam segala kebaikan, termasuk dalam memenuhi kebutuhan pribadinya yang paling kecil. 
e. Prinsip Solidaritas (tadlâmun, solidarité) (QS al-Taubah: 71)

Solidaritas memiliki nilai strategis dalam upaya menjadikan masyarakat guyub dan rukun. Setiap muslim dituntut untuk mengerti dan menghayati lingkungan sosialnya.

f. Prinsip Toleransi (tasâmuh, tolérance) (QS Hud: 118-119)

Prinsip ini bukan hanya berlaku untuk hubungan antar sesama muslim, tetapi yang terpenting adalah untuk pemeluk antar agama, terutama antara muslim dan non muslim.

g. Prinsip Keseimbangan (tawâzun, equilibre) (QS al-Syurâ:40; al-Rahmân: 60). Masyarakat yang dibentuk dan dikembangkan Islam menganut prinsip keseimbangan, yaitu seimbang antara hak dan kewajiban; seimbang antara individu dan masyarakat; seimbang antara hak individu dan kewajiban individu, dan seimbang antara hak masyarakat dan kewajiban masyarakat (Saifuddin, 1986: 69).

3. Akhlak Bersaudara

Islam mengatur persaudaraan antar sesama muslim dan antar sesama manusia. Islam membedakan antara persaudaraan sesama muslim dan persaudaraan sesama manusia. Perbedaan itu sebagai konsekuensi logis dari adanya perbedaan hak-kewajiban antara muslim dan non muslim. Paling tidak, perbedaan agama menjadikan hak dan kewajiban antara pemeluk masing-masing agama berbeda. Lebih jelasnya akhlak bersaudara antar sesama muslim dan antar sesama manusia dipisahkan sebagai berikut:

a. Persaudaraan Sesama Muslim

- Membalas salam sesama muslim (QS al-Nisấ: 86).

- Mendoakan saudaranya yang bersin dengan ucapan yarhamuka Allâh (HR Bukhari).

- Menengok saudaranya yang sakit, mengantar jenazah saudaranya yang meninggal, dan memenuhi undangan saudaranya (Hadis Muttafaq 'alaih).

- Memberikan nasehat kepada saudaranya apabila ia memintanya (HR Bukhari).

- Menyayangi saudaranya sebagaimana menyayangi dirinya sendiri (Hadis Muttafaq 'alaih).

- Tidak mengganggu dan menyakiti saudaranya (Hadis Muttafaq 'alaih). 
- Rendah hati dan tidak sombong terhadap saudaranya (QS Luqman: 18; HR Abu Dawud dan Ibn Majah).

- Tidak dibenarkan mendiamkan saudaranya lebih dari tiga hari (Hadis Muttafaq 'alaih).

- Tidak menggunjing dan merendahkan saudaranya, tidak dengki, su'udzdzan dan mencari kesalahan saudaranya (QS al-Hujurât: 11-12).

- Tidak mencaci maki saudaranya, baik waktu masih hidup atau sudah meninggal dunia (Hadis Muttafaq 'alaih).

- Tidak menipu saudaranya (QS al-Nisa': 112; HR Muslim).

- Tidak berkhianat dan berbohong terhadap saudaranya (QS al-Mâidah: 1; alBaqarah: 177; al-Isra': 34; Hadis Muttafaq 'alaih).

- Berakhlak mulia terhadap saudaranya (HR al-Hâkim dan Tirmidzi).

- Menghormati saudara tua dan mengasihi saudara muda (HR Abu Dawud dan Turmudzi).

- Berlaku adil terhadap saudaranya dan memperlakukannya secara layak (HR Bukhari).

- Memaafkan kesalahan saudaranya dan menutupi aib dan celanya (QS alMâidah: 13; al-Baqarah: 178; al-Syurâ: 40, al-Nur: 19 dan 22; HR Abu Dawud dan Tirmidzi).

- Menolong saudaranya yang membutuhkan pertolongan (QS al-Mâidah: 2; HR Muslim; Hadis Muttafaq 'alaih).

- Melindungi saudaranya apabila ia berlindung kepada Allah dan memberinya apabila meminta kepada Allah.

b. Persaudaraan Sesama Manusia (Muslim dan Non Muslim)

Seorang muslim harus senantiasa konsisten dengan aqidah yang sudah dimilikinya, yaitu meyakini dan rela bahwa Islam adalah satu-satunya agama Allah, sebagai satu sistem hidup dan satu kebulatan ajaran yang mutlak benar, universal, dan eternal. Dengan akidah itu, setiap muslim harus bersikap terhadap non muslim selama mereka tidak mengganggu atau melawan sebagai berikut:

- Tidak mengakui agama selain Islam.

- Tidak menjadikan non muslim sebagai wali/penguasa/pemilik kewenangan (QS Ali Imran: 27). 
- Berlaku adil terhadap non muslim (QS al-Mumtahanah: 8).

- Menyayangi non muslim (HR Ahmad dan Ibn Majah).

- Tidak mengganggu jiwa, harta, dan kehormatan non muslim (HR Muslim).

- Boleh memberi hadiah kepada non muslim dan boleh pula menerima hadiah dari mereka (QS al-Mâidah: 5).

- Mukminah (wanita yang beriman) tidak boleh dinikahi oleh lelaki non muslim (QS al-Mumtahanah: 10).

- Mendoakan non muslim ketika bersin dengan ucapan yuhdîkumu Allah wa yushlihu bâlakum.

- Tidak mendahului memberikan salam kepada non muslim, jika mereka memberi salam hendaknya dijawab dengan wa 'alaikum (Hadis Muttafaq 'alaih).

\section{Ukhuwwah dalam Praktek}

Akidah tauhid beserta prinsip-prinsip di atas secara keseluruhan telah dipraktekkan oleh Rasulullah Saw di Madinah. Praktek kebijakan Ukhuwwah yang diterapkan Rasulullah itu tertuang dalam Piagam Madinah (shahifah atau watsiqah). Piagam tersebut menjadi dostur atau constitution. Piagam Madinah yang menjadi bukti otentik sejarah tentang keharmonisan hubungan internal umat Islam dan hubungan eksternal antar umat, terdiri dari Pakta antara Muhajirin dan Anshar di satu pihak, dan di lain pihak Rekonsiliasi antara umat Islam dan orang Yahudi.

Piagam Madinah memuat antara lain bahwa masing-masing pihak, baik orang Muhajirin dan Anshar maupun orang Yahudi (ahli kitab) diakui dan dihormati eksistensinya; Muhajirin dan Anshar sebagai satu umat yang memiliki hak dan kewajiban yang sama, sedang orang Yahudi (ahli kitab) sebagai dzimmi yang memperoleh perlindungan dengan kompensasi ikut berpartisipasi dalam bela negara; Orang Yahudi (ahli kitab) memiliki kebebasan dalam melaksanakan agamanya dan kebebasan mempertahankan kultur tradisi mereka, sedang orang Muhajirin dan Anshar dilarang menyerupai orang-orang Yahudi (ahli kitab).

Orang-orang Muhajirin dianggap satu kelompok karena jumlah mereka relatif kecil, sedang suku-suku yang ada di dalam Anshar tetap diakui keberadaannya, mereka tidak dianggap satu kelompok. Pengakuan keberadaan masing-masing kelompok dan suku tersebut tidak berarti Islam membenarkan fanatisme. Pengakuan tersebut 
justeru mempermudah koordinasi untuk menggalang solidaritas sosial (Dr. Akram al'Umri dalam Bulletin of the Imam al-A'dham College No.1 hal. 45-57).

Piagam Madinah telah mampu menciptakan tata kehidupan yang harmonis antar sesama muslim dan antar sesama umat manusia di bawah pemerintahan Rasulullah di Madinah. Piagam Madinah di dalam aplikasinya didukung oleh syara', antara lain dalam sebuah hadis disebutkan bahwa Jibril senantiasa berpesan tentang tetangga, seolah-olah tetangga itu akan mewarisi. Hadis yang lain menyebutkan bahwa orang yang beriman adalah orang yang menghormati tamunya dan tidak menggangu tetangganya.

Berangkat dari hadis-hadis itu diketahui bahwa Rasulullah memperlakukan sesamanya secara santun, ramah, dan bersahabat. Rasulullah sampai-sampai menganjurkan kepada mereka yang hendak memasak supaya menambah kuahnya untuk bisa dibagikan kepada tetangganya. Seorang tetangga non muslim memiliki satu hak, yaitu hak sebagai tetangga. Tetangga muslim memiliki dua hak, yaitu hak tetangga dan hak muslim. Tetangga kerabat yang muslim memiliki tigak hak, yaitu hak tetangga, hak muslim, dan hak kerabat.

Contoh-contoh di atas masih bisa ditambah dengan sederetan contoh-contoh lain yang menggambarkan bahwa Islam benar-benar agama rahmatan lil 'alamin, agama kasih sayang untuk seluruh makhluk di jagad raya ini, agama pembawa kata damai, agama pemersatu umat manusia. Bukti lain dalam kehidupan antar umat beragama bisa dilihat, orang-orang non muslim yang hidup di suatu negara yang mayoritas penduduknya beragama Islam tidak pernah mengalami tekanan-tekanan, baik dalam beribadah sesuai dengan agamanya, maupun secara ekonomi, sosial, dan politik.

Keadaan menjadi berbeda ketika orang-orang Islam hidup di suatu negara yang mayoritas penduduknya beragama non Islam. Sebenarnya, mereka (umat Islam) melakukan reaksi atas tekanan mayoritas terkadang diwujudkan dalam bentuk aksi pemberontakan, atau mereka memilih menjadi golongan sparatis berjuang menentukan nasib sendiri. Perjuangan untuk auto-determination selalu dinilai dan diindentikkan sebagai aksi teror. 


\section{SIMPULAN}

Islam secara jelas dan tegas telah mengatur hubungan antar sesama umat Islam dan antar sesama umat manusia dengan menggunakan label Ukhuwwah Islamiyyah. Ukhuwwah ini lebih mengedepankan titik temu dan menjauhkan titik perbedaan dalam rangka menciptakan tata kehidupan yang harmonis, aman, tenteram, dan damai (rahmatan lil 'alamîn). Kendati Ukhuwwah yang diajarkan Islam memiliki nilai luhur dan universal, namun di dalam penerapannya amat sangat tergantung pada manusiamanusia yang terlibat dalam interaksi sosial yang melingkupinya. Pada tataran inilah Konsep Ukhuwwah Islamiyyah menjadi suatu keniscayaan sebagai materi Pendidikan Agama Islam (PAI) di sekolah-sekolah dan di madrasah-madrasah di seluruh wilayah tanah air tercinta ini dalam rangka untuk memperkokoh persatuan dan kesatuan sesama anak bangsa dalam bingkai Bhineka Tunggal Eka dan Negara Kesatuan Republik Indonesia (NKRI). Semoga.

\section{DAFTAR PUSTAKA}

Alquran dan Terjemahnya, tt, Madinah Munawarah: Mujamma' Khadim al-Haramain li thiba'at al-Mushhaf al-Syarif.

Abd. Karim Zaidan, 1976, Ushul al-Dakwah, Baghdad: Jam'iyah al-Amani.

Abu Bakr Jabiral-Jazairi, 1992, Minhaj al-Muslim, Bairut: Dâr al-Fikr.

Akram al-'Umri dalam Bulletin of the Imam al-A'dham College No.1

Ali Syariati, 1982, On the Sociology of Islam, terj., Yogyakarta: Ananda.

E. Saifuddin Anshari, 1986, Wawasan Islam, Jakarta: Rajawali.

Harsojo, 1988, Pengantar Antropologi, Bandung : Binacipta.

Ibn Manzur, 1968, Lisân al-Arab, Vol. XII, Bairut: Dâr Shâdir.

M. Quraish Shihab, 1997, Wawasan al-Quran, Bandung: Mizan.

Muhammad Abu Zahrah, tt, Tandhim al-Islam li al-Mujtama', Cairo: Dar al-Fikr al-Arabi.

Nurcholish Madjid, 1992, Islam: Doktrin dan Peradaban, Jakarta: Yayasan Wakaf Paramadina. 